\title{
Nursing habits and early childhood caries in children attending Hospital University Science Malaysia (HUSM)
}

\author{
Widowati Witjaksono*, Mon Mon Tin Oo**, and Khamisah Awang Kechik*** \\ * Department of Periodontic, University Science Malaysia School of Dental Sciences and Airlangga University \\ Faculty of Dentistry \\ ** Department of Community Dentistry, University Science Malaysia School of Dental Sciences \\ *** Year 5 student, University Science Malaysia School of Dental Sciences
}

\begin{abstract}
The habit of nocturnal bottle or breast-feeding has been reported to be a potential cause for early childhood caries (ECC) in very young children. The aim of this study was to determine the prevalence of ECC in children 2-5 years of age attending out patient clinic HUSM, in relation to the nursing habits. In this cross-sectional study, 90 children were randomly selected to examine their caries status using torch and disposable mirror. Data on mothers' educational level, nursing habits and oral hygiene practices, were gather by using structured questionnaire. It has been found that $16.7 \%$ of subjects were caries free while $83.3 \%$ of them had caries with mean dmf score 6 (SD 5.3). With regard to nursing habits, $29 \%$ of subjects had breast-feeding alone, $16 \%$ had bottle-feeding alone and 55\% had both breast and bottle-feeding. Ninety-three percent of children had been nursed beyond 14 months and $47 \%$ had been fed with liquids other than breast milk, infant formula or water. Twenty-seven percent of children were allowed to sleep with nursing bottle in mouth and 52\% were allowed to sleep with breast nipple in the mouth which shows significantly associated with ECC ( $p=0.03)$. Tooth brushing habit was reported for $91 \%$ of children using toothpaste. Mean age of the children (in months) when the mothers started brushing the teeth was 19.1 (SD 10.8) and has significant association with ECC $(p<0.05)$. This study demonstrates that the habit of allowing infants to sleep with breast nipple in their mouth and the late start of tooth brushing are associated with prevalence of ECC. Educational programs for pregnant women and mothers of young children should be emphasized to enhance the knowledge and awareness of mothers in preventing ECC.
\end{abstract}

Key words: early childhood caries, nursing habits, nursing bottle

Correspondence: Widowati, Periodontic Department University Science Malaysia, School of Dental Sciences, Health Campus, K. Kerian 16150, Kelantan, Malaysia. E-mail: widowati@kb.usm.my

\section{INTRODUCTION}

Children's oral health is dependent on the interest and ability of parents. Hence, oral health education is given to expectant mothers, so that home care can be started in early infancy. Despite this, in The National Oral Health Survey of School Children 1997, the researchers found that the proportion of 6 years old children with 1 or more carious teeth in deciduous dentition was $80.6 \% .^{1}$

Rampant caries in infants and young children has long been recognized as a clinical syndrome referred to by various names, including nursing caries, nursing bottle syndrome, night bottle mouth, and baby bottle tooth decay. The common theme among these terms is the perceived central role of inappropriate use of the baby bottle in the etiology and progression of carious lesions. Early childhood caries (ECC) is a unique pattern of dental caries in very young children due to prolonged and improper feeding habits. Even as the first primary tooth starts erupting, the oral environment can be conducive to the initiation of demineralization. In spite of the fact that dental caries is diminishing in our youth, there are still a large number of children with advanced multiple carious lesions, victims of parental ignorance of nursing caries which is a distinct clinical entity.

The primary factor is a pattern of sugar consumption that has been established early in life of the child. Other factors include feeding practices such as putting the child to bed at naptime, or bedtime with a bottle containing sweetened milk or beverages and inappropriate practice using a bottle containing milk, juice or other cariogenic substance as a pacifier for non-nutritive reasons. Prevalence of caries and maxillary anterior decay varies greatly in developed and underveloped countries and among socioeconomic groups in developed countries.

However, the onset and progression of the disease or the antecedents of ECC, such as high-risk behaviors, cultural norms, health beliefs and attitudes, or health care delivery factors is relatively unknown. Furthermore, studies that do exist are limited by small and possibly biased samples and a lack of clear case definition.

Evidence exists suggesting that the experience of ECC puts children at a significantly higher lifetime risk for dental caries and its sequelae, both in their primary and permanent 
dentitions. ${ }^{2}$ Children with ECC had more severe fissure caries and were more likely to develop posterior proximal caries than children without ECC. ${ }^{3}$ Early childhood caries (ECC) is a significant risk factor for later caries, and find that ECC children have more than twice the number of carious, extracted or restored teeth over the time spanned by their fourth to sixth years. ${ }^{4}$

Extraction and restoration are expensive procedures, and tooth loss may have a significant impact on the child's future dental development. The pain and discomfort associated with ECC may be responsible for the phenomena of low body weight and adversely affected growth observed in ECC children. ${ }^{5}$

The main purposes of this study were: to identify the prevalence of early childhood caries and the nursing habits amongst children age 2-5 years old attending HUSM and to determine the association between the nursing habits and caries status.

\section{MATERIALS AND METHODS}

A cross sectional study was conducted during May to June 2004 among randomly selected 90 children aged 2-5 years old who attended out patient clinic HUSM. Children with chronic or severe illness were excluded. A written informed consent form was obtained from the mother following an explanation of procedures.

Mothers were interviewed using structured questionnaire to obtain information regarding mother's educational level, feeding history and dietary habits of their child and oral hygiene practices. The oral examination of children was performed with the help of a mouth mirror and a pen light source. No attempt was made to probe the teeth and dental radiographs were not used in any of the examinations.

Caries experience was recorded using dmf index: ( $d=$ the number of decayed teeth, $m=$ the number of missing teeth which have been extracted due to caries, and $\mathrm{f}=$ the number of filled teeth). The criteria used for caries diagnosis were that of United Surveilances Summaries. ${ }^{6}$

Data were then compiled and analyzed using SPSS Version 11.0. The analyses to be used were descriptive statistics that is mean and standard deviation. As for the hypotheses, $\mathrm{Chi}^{2}$ test, Fisher's exact test, and Independent T-Test were used.

\section{RESULTS}

Table 1 showed the description of demographic variables among respondents. The children's ages ranged from 2 to 5 with median age of 4 . Mean age of mothers is 35.6 years and majority of them completed secondary school. Among them $66.7 \%$ are housewives and the rest are working mother.
Table 1. Description of study population

\begin{tabular}{|c|c|c|c|}
\hline Variable & Mean (SD) & $\begin{array}{l}\text { Median } \\
\text { (IQR) }\end{array}$ & Freq. $(\%)$ \\
\hline Mother's age & $35.6(6.6)$ & $4.0(2.0)^{\mathrm{a}}$ & - \\
\hline \multicolumn{4}{|l|}{$\begin{array}{l}\text { Mother's educational } \\
\text { level }\end{array}$} \\
\hline Primary school & & & $6(6.7)$ \\
\hline Secondary school & & & $73(81.1)$ \\
\hline Higher education & & & $11(12.2)$ \\
\hline \multicolumn{4}{|c|}{ Mother's working status } \\
\hline Working & & & $30(33.3)$ \\
\hline Housewife & & & $60(66.7)$ \\
\hline \multicolumn{4}{|c|}{ SD $=$ Standard Deviation } \\
\hline $\mathrm{IQR}=$ Interquartile & & & \\
\hline Freq $=$ Frequency & & & \\
\hline
\end{tabular}

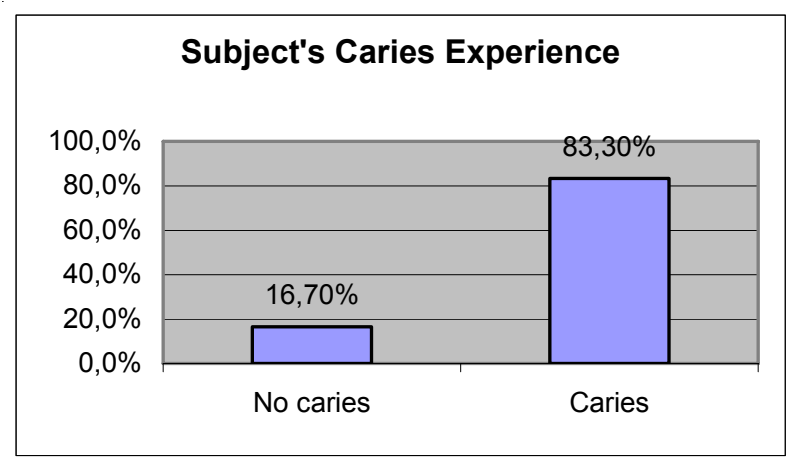

Figure 1. Caries experience of the study population.

For caries experience and prevalence of caries, this study showed $16.7 \%$ of children had dmf score 0 (caries free) while $83.3 \%$ of them had caries experience (Figure 1). Caries experience (dmf score) among children is shown in Table 2 by frequency distribution, the mean dmf score was 6 (SD 5.3). From statistical analysis, it was $95 \%$ sure that the prevalence of caries in the population will be between $75 \%$ and 91 .

In this study population prevalence of caries in male subjects was higher than female, which was $91.7 \%$ in male and $77.8 \%$ in female (Figure 2). As for nursing habits of subjects $29 \%$ percent of subjects had breast-feeding alone, $16 \%$ had bottle-feeding alone while other $56 \%$ had both breast and bottle-feeding. Ninety-three percent of them had been nursed beyond 14 months. Fifty-three percent of them had been fed with liquids other than breast milk, formula or water during their bottle-feeding. $27.8 \%$ were allowed to sleep with infant formula bottle in their mouth while $52 \%$ were allowed to sleep with breast nipple in the mouth. Only $10 \%$ of them had been allowed to take bottle without restriction, $40 \%$ of children were given water prior to sleep. Most of the mothers (91\%) reported that they brush their child's teeth using toothpaste. Mean age (in months) when mother start encouraging subjects to drink in cup was 20.5 $(\mathrm{SD} \pm 10.5)$. Mean age when mother started to brush their 
Table 2. Frequency distribution of dmf score among the study population

\begin{tabular}{cccc}
\hline dmf score & Frequency & Percent & Cum. \% \\
\hline 0 & 15 & 16.7 & 16.7 \\
$1-5$ & 31 & 34.4 & 51.1 \\
$6-10$ & 25 & 27.8 & 78.9 \\
$11-15$ & 12 & 13.3 & 92.2 \\
$16-20$ & 7 & 7.8 & 100 \\
\hline Total & 90 & 100.0 & 100.0 \\
\hline
\end{tabular}

Mean dmf score $=6($ SD 5.3)

Severe $\mathrm{ECC}=48.9 \%(\mathrm{dmf}>6)$

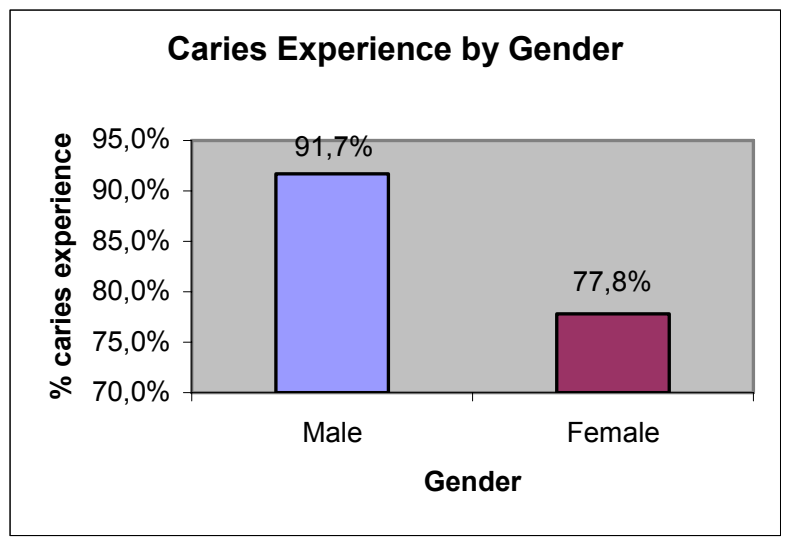

Figure 2. Caries experience of children showing by gender.
Table 3. Nursing habit of children

\begin{tabular}{lrr}
\hline \multicolumn{1}{c}{ Variable } & \multicolumn{1}{c}{ Yes } \\
& Freq (\%) & \multicolumn{1}{c}{$\begin{array}{c}\text { No } \\
\text { Freq (\%) }\end{array}$} \\
\hline Breast feeding alone & $26(28.9)$ & $64(71.1)$ \\
Bottle feeding alone & $14(15.6)$ & $76(84.4)$ \\
Breast feeding and bottle feeding & $50(55.6)$ & $40(44.4)$ \\
Nursed beyond 14 months & $84(93.3)$ & $6(6.7)$ \\
Fed with liquid other than breast & $48(53.3)$ & $42(46.7)$ \\
milk, formula or water & & \\
Sleep with infant formula bottle in & $25(27.8)$ & $65(72.2)$ \\
mouth & & \\
Sleep with breast nipple in mouth & $47(52.2)$ & $43(47.8)$ \\
Had bottle without restriction & $9(10.0)$ & $81(90.0)$ \\
Given plain water before sleep & $36(40.0)$ & $54(60.0)$ \\
Tooth-brushing practice & $82(91.1)$ & $8(8.9)$ \\
\hline
\end{tabular}

teeth (in months) was 19.1 ( $\mathrm{SD} \pm 10.8)$. Summary of nursing habits of the children is shown in Table 3 .

Caries experience and association factors are shown in Table 4. Among all categorical variables, the habit of allowing the infant to sleep with breast nipple in mouth is associated with caries experience, which is statistically significant $(\mathrm{p}=0.03)$. For numerical variables, age of subjects and age when started brushing teeth were significantly difference between caries and non-caries subjects $(\mathrm{p}<0.05)$ Table 5.

Table 4. Factors (categorical variables) associated with early childhood caries

\begin{tabular}{|c|c|c|c|c|c|}
\hline Variable & $\mathrm{n}$ & $\begin{array}{c}\text { Caries } \\
\text { Freq }(\%)\end{array}$ & $\begin{array}{c}\text { No Caries } \\
\text { Freq }(\%)\end{array}$ & $\begin{array}{c}X^{2} \text { statistic }^{a} \\
(\mathrm{df})\end{array}$ & $P$ value \\
\hline \multicolumn{6}{|l|}{ Gender } \\
\hline Male & 36 & 33(91.7) & $3(8.3)$ & $3.00(1)$ & 0.083 \\
\hline Female & 54 & $12(22.2)$ & $42(77.8)$ & & \\
\hline \multicolumn{6}{|l|}{ Mother's educational level } \\
\hline Primary and secundary school & 79 & $66(83.5)$ & $13(16.5)$ & & $1.000^{*}$ \\
\hline Higher educational level & 11 & $9(81.8)$ & $2(18.2)$ & & \\
\hline \multicolumn{6}{|l|}{ Mother's working status } \\
\hline Working & 30 & $23(76.7)$ & $7(23.3)$ & $1.44(1)$ & 0.230 \\
\hline Housewife & 60 & $52(86.7)$ & $8(13.3)$ & & \\
\hline \multicolumn{6}{|c|}{ Mother had received information about oral health } \\
\hline Yes & 27 & $21(77.8)$ & $6(22.2)$ & & $0.368 *$ \\
\hline No & 63 & $54(85.7)$ & $9(14.3)$ & & \\
\hline \multicolumn{6}{|l|}{ Breast feeding alone } \\
\hline Yes & 26 & $24(92.3)$ & $2(7.7)$ & & $0.215^{*}$ \\
\hline No & 64 & $51(79.7)$ & $13(20.3)$ & & \\
\hline \multicolumn{6}{|l|}{ Bottle feeding alone } \\
\hline Yes & 14 & $4(28.6)$ & $10(71.4)$ & & $0.240 *$ \\
\hline No & 76 & $65(85.5)$ & $11(14.5)$ & & \\
\hline \multicolumn{6}{|l|}{ Breast feeding and bottle feeding } \\
\hline Yes & 50 & $41(82.0)$ & $9(18.0)$ & $0.14(1)$ & 0.704 \\
\hline No & 40 & $34(85.0)$ & $6(15.0)$ & & \\
\hline \multicolumn{6}{|l|}{ Mother nursed child beyond 14 months } \\
\hline Yes & 84 & $69(82.1)$ & $15(17.9)$ & & $0.584 *$ \\
\hline No & 6 & $6(100.0)$ & $0(0.0)$ & & \\
\hline
\end{tabular}


Lanjutan Tabel 4.

\begin{tabular}{|c|c|c|c|c|c|}
\hline Variable & $\mathrm{n}$ & $\begin{array}{c}\text { Caries } \\
\text { Freq }(\%)\end{array}$ & $\begin{array}{l}\text { No Caries } \\
\text { Freq }(\%)\end{array}$ & $\begin{array}{l}\mathrm{X}^{2} \text { statistic }^{\mathrm{a}} \\
\quad(\mathrm{df})\end{array}$ & $\mathrm{P}$ value \\
\hline \multicolumn{6}{|c|}{$\begin{array}{l}\text { Mother use liquid other than breast milk,formula or } \\
\text { water to bottle feed }\end{array}$} \\
\hline Yes & 42 & $34(81.0)$ & $8(19.0)$ & $0.32(1)$ & 0.571 \\
\hline No & 48 & $41(85.4)$ & $7(14.6)$ & & \\
\hline \multicolumn{6}{|c|}{ Child fall asleep with infant formula bottle } \\
\hline Yes & 25 & $21(84.0)$ & $4(16.0)$ & & $1.000 *$ \\
\hline No & 65 & $54(83.1)$ & $11(16.9)$ & & \\
\hline \multicolumn{6}{|c|}{ Child fall asleep with breast nipple inside mouth } \\
\hline Yes & 47 & $43(91.5)$ & $4(8.5)$ & $4.71(1)$ & 0.030 \\
\hline No & 43 & $32(74.4)$ & $11(25.6)$ & & \\
\hline \multicolumn{6}{|l|}{ Child have bottle without restriction } \\
\hline Yes & 9 & $6(66.7)$ & $3(33.3)$ & & $0.169 *$ \\
\hline No & 81 & $69(85.2)$ & $12(14.8)$ & & \\
\hline \multicolumn{6}{|l|}{ Mother give plain water prior to sleep } \\
\hline Yes & 36 & $29(80.0)$ & $7(19.4)$ & $0.33(1)$ & 0.564 \\
\hline No & 54 & $46(85.2)$ & $8(14.8)$ & & \\
\hline \multicolumn{6}{|l|}{ Mother brush child's teeth } \\
\hline Yes & 82 & $68(82.9)$ & $14(17.1)$ & & $1.000 *$ \\
\hline No & 8 & $7(87.5)$ & $1(12.5)$ & & \\
\hline \multicolumn{6}{|c|}{ Mother use toothpaste when brushing child;s teeth } \\
\hline Yes & 77 & $65(84.4)$ & $12(15.6)$ & & 0.266 \\
\hline No & 6 & $4(66.7)$ & $2(33.3)$ & & \\
\hline
\end{tabular}

${ }^{a}$ Chi square test for independence

* Fisher's exact test

Table 5. Factors (numerical variable) associated with early childhood caries

\begin{tabular}{|c|c|c|c|c|c|}
\hline Variable & $\begin{array}{c}\text { Caries } \\
(\mathrm{n}=75) \\
\text { Mean }(\mathrm{SD})\end{array}$ & $\begin{array}{c}\text { No caries } \\
(\mathrm{n}=15) \\
\text { Mean }(\mathrm{SD})\end{array}$ & $\begin{array}{l}\text { Mean differ } \\
(95 \% \mathrm{CI})\end{array}$ & $\begin{array}{l}\text { t statistic } \\
\text { (df) }\end{array}$ & $P$ value \\
\hline Child's age (years) & $3.8(0.944)$ & $3.0(1.000)$ & $-0.9(-1.4,-0.3)$ & $-3.26(88)$ & 0.002 \\
\hline $\begin{array}{l}\text { Age when started to have drink from } \\
\text { cup (months) }\end{array}$ & 21.2(10.948) & $16.9(6.503)$ & $-4.37(-10.4,1.7)$ & $-1.44(87)$ & 0.153 \\
\hline $\begin{array}{l}\text { Age when started to brush teeth } \\
\text { (months) }\end{array}$ & $20.3(4.413)$ & 13.4(11.346) & $-6.90(-10.5,-3.3)$ & $-3.82(53)^{\mathrm{a}}$ & 0.000 \\
\hline
\end{tabular}

a Population variance were significantly different (Levene's test $\mathrm{P}$ value $=0.010$ ), therefore $\mathrm{t}$ ' test without assuming equal variance was used.

\section{DISCUSSION}

Early childhood caries is one frequently encountered problem for preschool age children in world wide. It is also well known that good oral hygiene and proper feeding habits should be established as early as possible in order to prevent ECC, which is certainly depending on mother's knowledge and practice. There is an association of low socio-economic status with parenting stress and the adoption of poor techniques for feeding and pacifying the child. ${ }^{7}$ Mother's education is one of the associated factors in Streptococcus mutan's count in children who were undergone treatment for ECC. ${ }^{8}$ From family factors mother's basic education comes to be significant during early childhood and poor dental health at 10 years of age. ${ }^{9}$

Although there were relationship between the children's caries experience and the number of missing teeth, dental attendance pattern and the level of education of the mother, ${ }^{10}$ in the present study the mother's education level is not related to ECC. This reality can be due to the fact that most of the mothers had received the information about children's oral health but they were not practicing the proper way to nurse their child and taking care of their child's teeth. The study of Syahril et al. ${ }^{11}$ also revealed that these attitude were not reflected in the dental health status of their children, eventhough parents had adequate knowledge and positive attitude to their children's dental care.

The prevalence of ECC in this study population is high (48.9\% with dmf > 6) compared to western population in Greater Manchester, ${ }^{12}$ whereby $32 \%$ children affected by caries and dmfs was 2.8 which has to be considered as severe ECC. ${ }^{12,13}$

In South East Asia countries including Malaysia, the prevalence of caries is also still high, such as caries 
prevalence of children aged 2-6 years old in northern Philippines that were 59-92\%. ${ }^{14}$ The high prevalence of caries shows their low level of caries awareness and its consequences in those countries.

Regarding nursing habits of respondents this study indicated the significant association between ECC and the habit of allowing the infants to sleep at night with breast nipple in their mouth (ad libitum nocturnal breast feeding). Similarly in the Dutch study, Weerheim et al. ${ }^{15}$ found that nursing caries group was significantly morelikely to have been given the breast frequently at night through the age of 18 months.

These significant association may be due to given breast-feeding together with bottle-feeding until they were over 14 months and the age encouraging their infants to have drink from a cup was about 20.5 months. These were far different from the American Academy of Paediatric Dentistry (AAPD) suggestions that infants should be weaned from the bottle at 12 to 14 months of age and should be encouraged to have drinks from a cup as they approach their first birthday. ${ }^{16}$ Despite the changing of feeding habit offend a young child, it is parent's responsibility to adopt the appropriate feeding practices for prevention of ECC.

In this study 48 mothers used nursing bottle to feed liquids other than breast milk or formula of water. Sweetened liquids, which have a minimal nutrient content, mainly contain carbohydrate, increase the risk of caries due to prolong contact between sugar and cariogenic bacteria on susceptible teeth. In addition, allowing the infant to fall asleep at naps or bedtime with the bottle inside mouth is also inappropriate use of nursing bottles. Although these nursing habits were not significantly associated, it was obvious that mothers who participated in this study did not practice a proper way of feeding.

American Academy of Paediatric Dentistry (AAPD) encourages that oral hygiene measures should be implemented by the time of eruption of the first primary tooth. ${ }^{16}$ Although $91.1 \%$ of respondents from this study reported cleaned their infant teeth by using toothbrush and toothpaste however, mean age when started to brush (in months) was 19.1 ( $\mathrm{SD} \pm 10.8)$ which is rather late. There was statistically significant relationship among the age of start brushing teeth and ECC, whereas mean age (in months) in caries group is $20.3(\mathrm{SD} \pm 4.4)$ while in non-caries group 13.4 (SD \pm 11.3 ). This result showed the importance of early practice of tooth brushing that can prevent from developing ECC.

This study also showed an association between age of the child and caries prevalence where mean age of caries group (in years) was $3.8(\mathrm{SD} \pm 0.9)$ while for non caries group was $3(\mathrm{SD} \pm 1.0)$. This result also supported by the study of parents and nursing-bottle caries, ${ }^{17}$ that reported children with caries and non caries were differ in two respects; caries children on the whole are older and they have been sick more often than non caries children.
This might be due to increase exposure of sugary food and containing fermentable carbohydrate when the child's age increases.

As the mother plays an important role in maintaining their children's oral health, the authors suggest that early educational, intervention programs should be developed for pregnant mothers and mothers of young children. Comprehensive anticipatory guidance in the areas of nursing habits, diet and nutrition, oral hygiene practices, fluoride use, causes and sequelae of ECC and early dental visits should be emphasized to enhance the knowledge and awareness of mother in prevention of ECC.

\section{REFERENCES}

1. Ministry of Health Malaysia. The National Oral Health Survey of School Children. 1997.

2. NIH Consensus Statement. Diagnosis and management of dental caries throughout life. On line March 26-28, 2001; 18(1):1-24.

3. Douglass JM, DM O'Sullivan, N Tinanoff. Temporal changes in dental caries levels in a Native American pre-school population. J Public Health Dent 1996; 56(4):171-5.

4. Thakib, et al. Primary incisor decay before age 4 as a risk factor for future dental caries. Paediatric Dentistry 1997; 19:37-41.

5. Ahyan H, Suskan E, Yildirim S. The effect of nursing or rampant caries on height, body weight and head circumference. Journal of Clinical Paediatric Dentistry 1996; 20(3):209-12.

6. United States Surveilance Summaries. Surveilance for dental caries, dental sealants, tooth retention, edentulism, and enamel fluorosis. August 26, 2005; 54(03):1-44.

7. Reisine S, Litt M. Social and psychological theories and their use of dental practice. International Dental Journal 2004; 43 (3 Supplement 1):279-87.

8. Peretz B, Sarit F, Eidelman E, Steinberg D. Mutans streptococcus counts following treatment for ECC. Journal of Dentistry for Children 2003 May-August; 70(2):111-4.

9. Mattila ML, Rautava P, Aromaa M, Ojanlatva A, Paunio P, Hyssala L, Helenius H, Sillanpaa M. Behavioural and demographic factors during early childhood and poor dental health at 10 years of age. $J$ of Caries Res 2005 March-April; 39(2):85-91.

10. Grytten J, Rossow I, Holst D, Steele L. Longitudinal study of dental health behaviours and other caries predictors in early childhood. Community Dent Oral Epidemiology 1988 December; 16(6):356-9.

11. Syahril D, Abdul-Kadir R, Yassin Z, Jali NM. Knowledge and attitudes of parents of children with nursing bottle syndrome in Serdang, Malaysia. J Nihon Univ Sch Dent 1995 Sept; 37(3): $146-51$.

12. Ismail Al, Sohn W. A systematic review of clinical diagnosing criteria of ECC. J Public Health Dent 1999; 59:171-91.

13. Davies GM, Blinkhorn FA, Duxbury JT. Caries among 3-year-olds in Greater Manchester. Br Dent J 2001; 190:381-4.

14. Carino KM, Shinada K, Kawaguchi Y. Early childhood caries in northern Philippines. Community Dent Oral Epidemiol 2003 Apr; 31(2):81-9.

15. Weerheim KL, Uyttendaele-Speybrouck BF, Euwe HC, Groen HJ. Prolong demand breast-feeding and nursing caries. Caries Res 1998; 32(1):46-50.

16. The American Academy of Paediatric Dentistry. Policy on early childhood caries (ECC): classifications, consequences and preventive strategies. 2003.

17. van Everdingen T, Eijkman MA, Hoogstraten J. Parents and nursing bottle caries. ASDC Journal of Dentistry for Children 1996; 63(6):426-33. 